\title{
Susceptibility to common insecticides and detoxifying enzyme activities in Anopheles sundaicus (sensu lato) after cessation of indoor residual spraying of insecticides in the Jaffna Peninsula and its surroundings in northern Sri Lanka
}

Kokila Sivabalakrishnan', Thilini C. Weerarathne², Amirtharasa Thileepan³ , S. H. P. Parakrama Karunaratne², Ranjan Ramasamy ${ }^{4}$ and Sinnathamby N. Surendran ${ }^{1 *}$ (D)

\begin{abstract}
Background: Sri Lanka has been malaria-free since 2013 but re-introduction of malaria transmission by infected overseas travelers is possible due to a prevalence of potent malaria vectors. Knowledge of the insecticide resistance status among Anopheles vectors is important if vector control has to be reintroduced in the island. The present study investigated the insecticide susceptibility levels and resistance mechanisms of Anopheles sundaicus (sensu lato) (previously classified as Anopheles subpictus species B) an important malaria vector in the Jaffna Peninsula and it surroundings in northern Sri Lanka after indoor residual spraying of insecticides was terminated in 2013.

Results: Species-specific PCR assays identified An. sundaicus (s.l.) in four locations in the Jaffna and adjacent Kilinochchi districts. Bioassays confirmed that An. sundaicus (s.l.) collected in Kilinochchi were completely susceptible to $0.05 \%$ deltamethrin and $5 \%$ malathion and resistant to $4 \%$ dichlorodiphenyltrichloroethane (DDT), whereas those from Jaffna were relatively susceptible to all three insecticides. Kilinochchi populations of An. sundaicus (s.l.) showed significantly higher glutathione S-transferase activity than population from Jaffna. However, Jaffna An. sundaicus (s.l.) had significantly higher Propoxur-resistant acetylcholinesterase activity. Activities of non-specific esterases and monooxygenases were not significantly elevated in An. sundaicus (s.l.) collected in both districts.

Conclusions: The susceptibility to malathion and deltamethrin in An. sundaicus (s.l.) suggests that they can be still used for controlling this potential malaria vector in the Jaffna Peninsula and adjacent areas. Continuing countrywide studies on other malaria vectors and their insecticide susceptibilities are important in this regard.
\end{abstract}

Keywords: Anopheles sundaicus complex, Jaffna Peninsula, Insecticide-detoxifying enzymes, Insecticide resistance bioassays, Malaria, Mosquito vectors, Sri Lanka

\footnotetext{
* Correspondence: noble@univ.jfn.ac.lk

${ }^{1}$ Department of Zoology, Faculty of Science, University of Jaffna, Jaffna, Sri Lanka

Full list of author information is available at the end of the article
}

(c) The Author(s). 2019 Open Access This article is distributed under the terms of the Creative Commons Attribution 4.0 International License (http://creativecommons.org/licenses/by/4.0/), which permits unrestricted use, distribution, and reproduction in any medium, provided you give appropriate credit to the original author(s) and the source, provide a link to the Creative Commons license, and indicate if changes were made. The Creative Commons Public Domain Dedication waiver (http://creativecommons.org/publicdomain/zero/1.0/) applies to the data made available in this article, unless otherwise stated. 


\section{Background}

Malaria had been endemic in Sri Lanka for centuries until indigenous transmission was eliminated from the island in 2013 [1]. However, many cases of malaria-infected travelers arriving from endemic countries are reported every year and therefore the potential for resuming indigenous transmission remains high due to the prevalence of many anopheline vectors in the island [1]. This challenge is exacerbated by the recent spread from India of the efficient urban malaria vector Anopheles stephensi to Sri Lanka [2, 3]. The Jaffna Peninsula in the Jaffna District and areas surrounding the Jaffna lagoon in the Kilinochchi District in northern Sri Lanka are coastal areas that were badly affected by malaria during the three decades of armed conflict that ended in 2009. The Anti-Malaria Campaign (AMC) in the north, specifically in the Kilinochchi District, faced logistic problems and a shortage of resources for its malaria control activities during the war.

Anopheles culicifacies species E was the major malaria vector in Sri Lanka while An. annularis, An. subpictus (s.l.) and An. sundaicus (s.l.) functioned as important secondary vectors together with other minor vectors before the elimination of malaria [4-10]. Anopheles subpictus exists as a species complex with members showing different bio-ecological traits relevant to malaria transmission [11, 12]. However, molecular genetic characterization of the An. subpictus complex after 2010 showed that mosquitoes previously identified morphologically as sibling species A, $\mathrm{C}$ and $\mathrm{D}$ belonged to a single group termed species $\mathrm{A}$, while sibling species B belonged to the An. sundaicus complex $[9,10]$, a major vector of malaria in coastal zones of many Southeast Asian countries [13]. In Sri Lanka too An. sundaicus (s.l.) is mainly found in coastal zones [9, 10], which include the $1130 \mathrm{~km}^{2}$ Jaffna Peninsula and areas in the Jaffna and Kilinochchi districts that surround the Jaffna Lagoon [14].

Killinochchi and Jaffna districts in the Northern Province were among the previously malaria endemic administrative districts. The civil war of 1983-2009 in north and east of Sri Lanka limited studies on malaria vectors to a few in the Jaffna District. These studies suggested that morphologically characterized An. subpictus (s.l.) was the predominant anopheline species in Jaffna $[15,16]$ with a higher sporozoite rate than $A n$. culicifacies [17]. The An. sundaicus (s.l.) identified at that time exclusively by morphology as An. subpictus species B, was the predominant anopheline species collected in 2008 from locations in the Jaffna District [15]. It was also found in 2008 that An. subpictus species B [now regarded as An. sundaicus (s.l.)] as well as $A n$. subpictus species $\mathrm{C}$ and $\mathrm{D}$ (now regarded as An. subpictus A) were susceptible to $5 \%$ malathion but highly resistant to $4 \%$ dichlorodiphenyltrichloroethane (DDT) [15].

We previously reported insecticide susceptibility and resistance mechanisms in members of the An. subpictus complex, including sibling species $\mathrm{B} / \mathrm{An}$. sundaicus (s.l.), collected from sites in the North Western and Eastern provinces of Sri Lanka (Fig. 1) [18], but the study excluded the Northern Province because of the ongoing civil war. We have now extended this study to

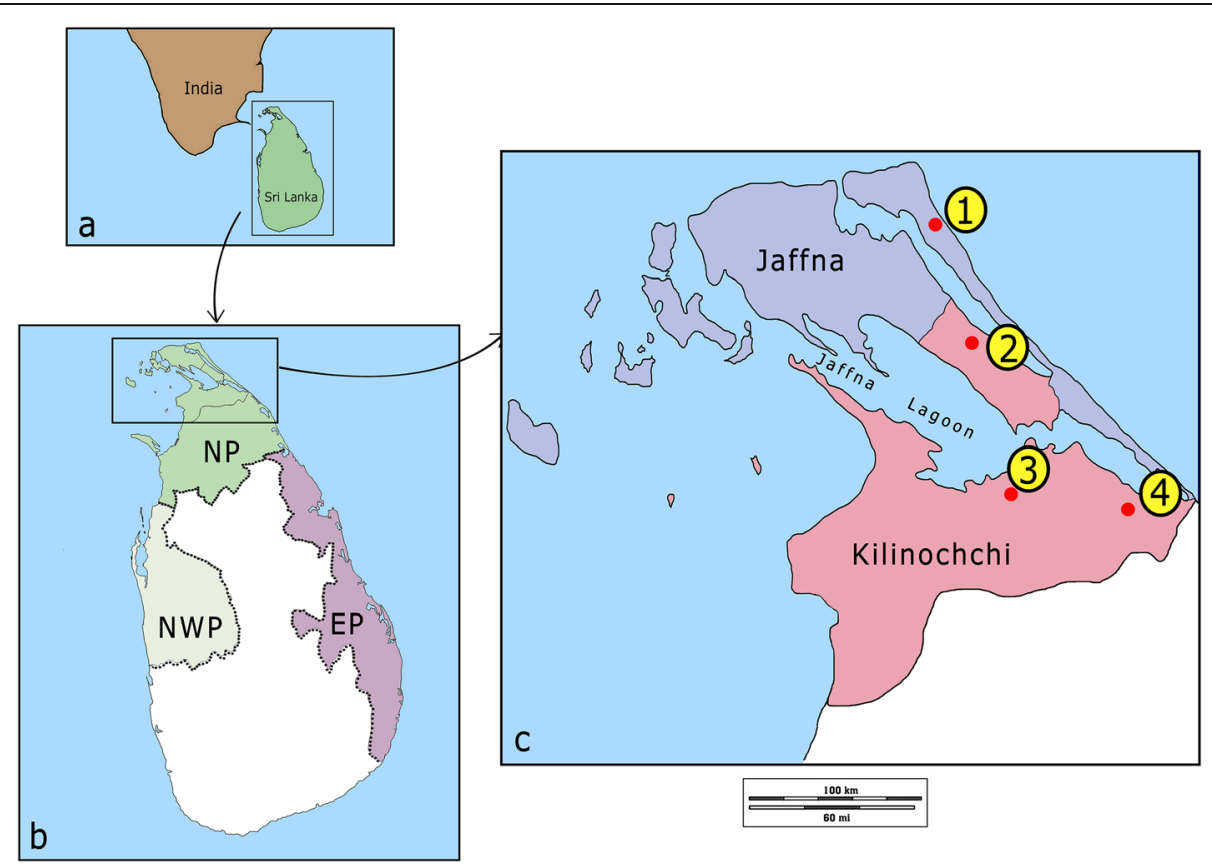

Fig. 1 Locations of study sites. a Location of Sri Lanka in relation to India. b Administrative boundaries of Northern Province (NP), Eastern Province (EP) and North Western Province (NWP). c Locations of sample collection sites (1-4) in the districts of Jaffna and Kilinochchi 
An. sundaicus (s.l.) collected from sites in the Jaffna Peninsula or its vicinity in the districts of Jaffna and Kilinochchi in the Northern Province. Understanding the insecticide resistance status and its biochemical basis in malaria vectors is important for vector control should indigenous malaria transmission re-emerge in the country.

\section{Methods}

\section{Study locations, sample collection and species} identification

Adult anopheline mosquitoes were collected monthly for 15 months from December 2014 to February 2016 using cattle baited hut $(\mathrm{CBH})$, cattle baited net (CBN) and indoor (IC) collection techniques $[9,10,18]$ from three locations in the Kilinochchi District (Palai, Kandavalai and Iranaimadu) and one location (Kudathanai) in the Jaffna District (Fig. 1). These study sites were selected based on their previous malaria endemicity and coastal proximity. Each location had two or more mosquito collection points: 1 . Kudathanai (3.4 km from the nearest coast) had four mosquito collection points $\left(9^{\circ} 44^{\prime} 47.5332 " \mathrm{~N}, 80^{\circ}\right.$ $16^{\prime} 19.9956^{\prime \prime} \mathrm{E} ; \quad 9^{\circ} 44^{\prime} 49.2828^{\prime \prime} \mathrm{N}, \quad 80^{\circ} 16^{\prime} 21.9288^{\prime \prime} \mathrm{E} ; \quad 9^{\circ}$ $44^{\prime} 49.2432^{\prime \prime} \mathrm{N}, \quad 80^{\circ} 16^{\prime} 25.1328^{\prime \prime} \mathrm{E} ;$ and $9^{\circ} 44^{\prime} 44.9052^{\prime \prime} \mathrm{N}, 80^{\circ}$ $1624.5532 " \mathrm{E})$; 2. Palai (3 km from the nearest coast) had three mosquito collection points $\left(9^{\circ} 36^{\prime} 26.838^{\prime \prime} \mathrm{N}, 80^{\circ} 19^{\prime} 44\right.$. $3892 " \mathrm{E} ; 9^{\circ} 36^{\prime} 34.6032 " \mathrm{~N}, \quad 80^{\circ} 19^{\prime} 55.8228^{\prime \prime} \mathrm{E}$; and $9^{\circ} 36^{\prime} 20$. $\left.4372 " \mathrm{~N}, 80^{\circ} 19^{\prime} 51.0312^{\prime \prime} \mathrm{E}\right) ; 3$. Iranaimadu (16 km from the nearest coast) had two mosquito collection points $\left(9^{\circ} 20^{\prime} 45.9708^{\prime \prime} \mathrm{N}, \quad 80^{\circ} 24^{\prime} 38.7432^{\prime \prime} \mathrm{E}\right.$ and $9^{\circ} 20^{\prime} 36.0636^{\prime \prime} \mathrm{N}$, $80^{\circ} 25^{\prime} 19.8408^{\prime \prime} \mathrm{E}$ ); and 4. Kandavalai (2 $\mathrm{km}$ from the nearest coast) had three mosquito collection points $\left(9^{\circ}\right.$ $27^{\prime} 14.1444 " \mathrm{~N}, \quad 80^{\circ} 29^{\prime} 9.7944^{\prime \prime} \mathrm{E} ; \quad 9^{\circ} 27^{\prime} 38.2212^{\prime \prime} \mathrm{N}, \quad 80^{\circ}$ $29^{\prime} 13.1964 " \mathrm{E}$; and $\left.9^{\circ} 27^{\prime} 12.618^{\prime \prime} \mathrm{N}, 80^{\circ} 29^{\prime} 38.5332 " \mathrm{E}\right)$.

Larval collections (LC) were carried out at each location from stagnant water bodies, e.g. sand pools and ponds, with $350 \mathrm{ml}$ dippers and then reared as described previously under contained conditions in the insectary of the Department of Zoology, University of Jaffna to reach adulthood [18]. Larvae were maintained under laboratory conditions $\left(28 \pm 2{ }^{\circ} \mathrm{C}, 12 \mathrm{~h}\right.$ photoperiod and $\sim$ $70 \%$ relative humidity) in the same water from the habitats where they were collected in 1.51 capacity plastic trays with powdered fish meal given twice a day as additional food.

The collected anopheline mosquitoes and emerging adults from LC were identified morphologically as previously described $[10,18,19]$. Morphologically-identified blood-fed An. subpictus (s.l.) adults were maintained in the insectary to obtain F1 progeny as described previously [20]. Adults emerged from LC and F1 progeny of blood-fed An. subpictus (s.l.) mosquitoes were transferred to adult mosquito cages and fed on sugar pledgets. Other anopheline species identified in the collections were not processed for analysis. Three- to five-day-old An. subpictus (s.l.), the F1 progeny of field-collected adult females, as well as adults obtained from field-collected larvae were used for insecticide bioassays, biochemical assays and DNA-based identification.

\section{Bioassays for insecticide susceptibility}

The standard World Health Organization (WHO) procedures were followed to determine the insecticide susceptibility status of adult mosquitoes [21]. Non-blood fed adult mosquitoes from the F1 progeny of field-collected blood-fed female mosquitoes and those developing from field-collected larvae in the Kilinochchi and Jaffna districts respectively, were pooled and separately tested for each district collection in duplicate assays with the WHO discriminating dosages of $0.05 \%$ deltamethrin, $5 \%$ malathion and 4\% DDT using WHO bioassay test kits as previously described [18]. The WHO criteria were used to define a population as susceptible ( $>98 \%$ mortality), suspected for resistance (90-98\% mortality) and resistant (<90\% mortality) [22].

A total of 76 mosquitoes collected from the Jaffna ( $n$ $=37)$ and Kilinochchi $(n=39)$ districts identified morphologically were confirmed by PCR. This included 19 and 24 blood-fed females collected in the field at the sites in the Jaffna and Kilinochchi districts respectively that gave rise to F1 adult progeny used in the insecticide bioassay and enzyme assays in addition to adults that emerged from larval collections. A total of 397 and 305 adults derived from F1 progeny and field-collected larvae from Kilinochchi and Jaffna districts, respectively, were used for bioassays. These were made up of 66 and $90 \%$ of the F1 progeny of the adults that were used for species-specific PCR assays from Jaffna and Kilinochchi districts, respectively. Similarly, out of the 80 mosquitoes used for enzyme assays, 84 and 68\% were from the F1 progeny of the blood-fed adults that were tested for species identification from sites in the Jaffna and Kilinochchi districts, respectively.

\section{Biochemical assays}

Adult female mosquitoes emerging from $\mathrm{F} 1$ progeny and LC collections were subjected to biochemical assays using the microplate method described previously [18]. Eighty individuals from each district were subjected individually to total protein, carboxylesterase (EST), glutathione S-transferase (GST), monooxygenase (MO) and acetylcholinesterase (AChE) assays as described previously [18]. Specific activities of $>0.25 \mu \mathrm{mol} / \mathrm{mg} / \mathrm{min}$ for $\mathrm{EST},>0.40 \mu \mathrm{mol} / \mathrm{mg} / \mathrm{min}$ for GST, and $>0.35$ equivalent units for $\mathrm{MO}$ were considered to be discriminating activity levels that can contribute to metabolic resistance in An. subpictus (s.l.) in Sri Lanka [18, 23]. According to WHO guidelines, remaining AChE activities after 
Propoxur inhibition in $>70 \%, 30-70 \%$ and $<30 \%$ of the population were categorized as homozygous resistant (RR), heterozygous resistant (RS) and homozygous susceptible (SS), respectively [24].

\section{Allele-specific PCR assay (AS-PCR) to distinguish An. sundaicus from An. subpictus}

DNA from adult females that gave F1 progeny and individual mosquitoes emerging from field-collected larvae was extracted using Qiagen DNeasy Blood \& Tissue Kit (Qiagen, Hilden, Germany) according to the manufacturer's instructions. The extracted DNA was used for diagnostic allele specific PCR as described previously [10]. The diagnostic size of the PCR product for $A n$. subpictus species A was $\sim 300$ bp while that for $A n$. sundaicus (s.l.) was $\sim 400$ bp as previously reported [10].

\section{Data analysis}

The two-tailed Student's t-test for matched samples was performed to determine significant differences between the Kilinochchi and Jaffna mosquito populations in the susceptibility to insecticides and enzyme activities of GST, EST and MO. The Chi-square test was performed to assess significant differences in proportions of the three categories of AChE (SS, RS and RR) between mosquitoes collected in the two districts.

\section{Results}

During the 15 month study period a total of 980 and 752 adults were morphologically identified as $A n$. subpictus (s.l.) from collections in the Kilinochchi and Jaffna districts, respectively. Anopheles annularis, An. barbirostis, An. culicifacies (s.l.), An. jamsai and An. psedojamsai were present in the collections but not used in the studies. The collected An. subpictus (s.l.) from both districts collectively comprised $53,25,19$ and $3 \%$ of mosquitoes collected by LC, CBN, CBH and IC, respectively.

Mosquitoes collected from Kilinochchi showed 100\% mortality to both $0.05 \%$ Deltamethrin and 5\% malathion and but only $31 \%$ mortality to $4 \%$ DDT indicating resistance to DDT. Although mosquitoes collected from Jaffna showed high mortality with deltamethrin (97\%), malathion (96\%) and DDT (91\%), the results indicate the possibility of some resistance to all three insecticides according to the WHO criteria $[21,22]$. The Kilinochchi population showed significantly higher resistance to DDT than Jaffna population, but there were no statistically significant differences in susceptibility to deltamethrin and malathion between the two districts (Table 1).

The enzyme activities and the percentage of mosquito populations that had enhanced enzyme activities are shown in Table 2. Although significantly different activities of EST $\left(t_{(155)}=3.76, P<0.001\right)$ and $\mathrm{MO}\left(t_{(150)}=15.53, P<0.001\right)$ were observed between the Kilinochchi and Jaffna population, neither population alone or collectively had activities of the two enzymes above the discriminatory levels for resistance reported for Sri Lankan An. subpictus (s.l.) [23]. Significantly $\left(t_{(148)}=-16.98, P<0.001\right)$ elevated GST activities above the reported discriminatory levels were seen in all of the Kilinochchi population compared with only $30 \%$ of the Jaffna population. The results of AChE assays to detect the percentage remaining activityof $\mathrm{AChE}$ in the presence of Propoxur are also presented in Table 2. The Chi-square test revealed a significant $\left(\chi^{2}=13.41, P=\right.$ 0.0012 ) association between the districts and the remaining activity of AChE in the three WHO categories of resistance, with the Jaffna An. sundaicus (s.l.) mosquitoes showing a greaterAChE active site alteration than in Kilinochchi.

\section{Discussion}

Because the PCR assays (Fig. 2) revealed that all 76 tested specimens belonged to An. sundaicus (s.l.), and all An. subpictus species B-like mosquitoes recently independently identified through existing morphological criteria in coastal and inland northern Sri Lanka were shown genetically belong to the An. sundaicus complex $[9,10]$, it is reasonable to assume that the vast majority, if not all the mosquitoes tested in the insecticide bioassay and enzymatic assays, are An. sundaicus (s.l.) and not An. subpictus species A. To our knowledge, the present study is the first to investigate insecticide resistance and insecticide resistance mechanisms in An. sundaicus (s.l.) in the Northern Province of Sri Lanka.

The greater resistance to DDT of mosquitoes from Kilinochchi compared to Jaffna may be due the higher prevalence of elevated GST activity in Kilinochchi compared with Jaffna. DDT resistance in morphologically identified An. subpictus (s.l.) was first reported in 1969 and a reduction in resistance was detected after

Table 1 Mortality in An. sundaicus (s.l.) exposed to three insecticides

\begin{tabular}{|c|c|c|c|c|}
\hline \multirow[t]{2}{*}{ Insecticide } & \multicolumn{2}{|c|}{ Mean $\%$ mortality \pm SD (no. of mosquitoes tested) } & \multirow[t]{2}{*}{$t$-value } & \multirow[t]{2}{*}{$P$-value } \\
\hline & Kilinochchi & Jaffna & & \\
\hline Deltamethrin (0.05\%) & ${ }^{s_{1}} 00(110)$ & $v_{97.3 \pm 3.8(100)}$ & $t_{(8)}=-3.0$ & 0.09 \\
\hline Malathion (5\%) & ${ }^{s_{1}} 00(136)$ & $v_{96.4} \pm 0.7(105)$ & $t_{(10)}=-2.0$ & 0.18 \\
\hline DDT (4\%) & $R_{30.9} \pm 8.7(151)$ & $v_{91.2} \pm 0.3(100)$ & $t_{(8)}=31.3$ & 0.01 \\
\hline
\end{tabular}

Abbreviations: $S$ susceptible ( $\geq 98 \%$ mortality), $R$ confirmed resistance $(<90 \%$ mortality), $V$ possible resistance and verification needed ( $90-97 \%$ mortality) [22], $S D$ standard deviation 
Table 2 Anopheles sundaicus (s.l.) populations with discriminating activities of GST, EST and MO and insensitive target site AChE

\begin{tabular}{|c|c|c|c|c|c|c|c|}
\hline \multirow[t]{2}{*}{ District } & \multirow[t]{2}{*}{ Enzyme activity profiles } & \multicolumn{3}{|l|}{ AChE $(\%)^{a}$} & \multirow[t]{2}{*}{$\mathrm{GST}^{\mathrm{b}}$} & \multirow[t]{2}{*}{$\mathrm{EST}^{\mathrm{c}}$} & \multirow[t]{2}{*}{$M O^{d}$} \\
\hline & & $<30[\mathrm{SS}]$ & $30-70[\mathrm{RS}]$ & $>70[\mathrm{RR}]$ & & & \\
\hline \multirow[t]{2}{*}{ Jaffna district } & $\begin{array}{l}\% \text { population(a) in different categories } \\
\text { and (b-d) with elevated activities }\end{array}$ & 50 & 35 & 15 & 30 & 0 & 0 \\
\hline & Mean activity \pm SE & & & & $0.38 \pm 0.02$ & $0.04 \pm 0.002$ & $0.03 \pm 0.001$ \\
\hline \multirow[t]{2}{*}{ Kilinochchi district } & $\begin{array}{l}\% \text { population(a) in different categories } \\
\text { and (b-d) with elevated activities }\end{array}$ & 78 & 17 & 5 & 100 & 0 & 0 \\
\hline & Mean activity \pm SE & & & & $1.85 \pm 0.08$ & $0.06 \pm 0.004$ & $0.003 \pm 0.001$ \\
\hline \multirow[t]{2}{*}{ Pooled data for both districts } & $\begin{array}{l}\% \text { population (a) in different categories } \\
\text { and (b-d) with elevated activities }\end{array}$ & 68 & 23 & 9 & 69 & 0 & 0 \\
\hline & Mean activity \pm SE & & & & $1.14 \pm 0.09$ & $0.06 \pm 0.004$ & $0.02 \pm 0.002$ \\
\hline
\end{tabular}

Abbreviation: SE standard error of the mean

${ }^{\text {a }}$ Percent remaining activity of AChEs in individual mosquitoes after Propoxure inhibition in homozygous (SS) sensitive, heterozygous (RS) and homozygous (RR) insensitive populations [24]

${ }^{b}$ Percentage of population having glutathione S-transferase (GST) discriminant specific activity above $0.40 \mu \mathrm{mol} / \mathrm{mg} / \mathrm{min}$ and $\mathrm{mean}$ specific activities

${ }^{c}$ Percentage of population having esterase (EST) discriminant specific activity above $0.25 \mu \mathrm{mol} / \mathrm{mg} / \mathrm{min}$ and mean specific activities

${ }^{\mathrm{d}}$ Percentage of population having monooxygenase (MO) levels above the discriminant activity of 0.35 units per mg protein of cytochrome $\mathrm{P}_{450}$ and mean specific activities $[18,23]$

cessation of DDT use for IRS and its replacement with malathion in the early 1970 s $[1,25]$. Later, due to the development of a GST-based resistance mechanism, which was suggested to be favored by high DDT application prior to malathion introduction, an increase in the DDT-resistant population was observed among An. subpictus complex [suspected to be a mixture of An. subpictus species A and An. sundaicus (s.l.)] after 1983 [26, 27]. No elevation of EST or MO was detectable in the two populations, suggesting that that EST and MO do not contribute to DDT resistance in the two districts.

Anopheles sundaicus (s.l.) populations, except that of Northern Province, are reported to have developed resistance to pyrethroid insecticides in other parts of the country [23]. Perhaps the relatively limited previous use of pyrethroids for vector control in the two northern districts for IRS and the absence of elevated ES and MO might be the reason for the observed relative susceptibility to deltamethrin. The results suggest that the Jaffna An. sundaicus (s.l.) mosquitoes may show weak resistance to deltamethrin but confirming this and the investigating potential underlying mechanisms requires more extensive investigation. The higher percentage remaining activity of AChE seen in the Jaffna population may be due to a continuing and more intensive use of organophosphate and carbamates pesticides for agriculture in the Jaffna Peninsula. Further studies with more sampling sites from both districts are needed to establish this.

Indoor residual spraying (IRS) was, until recently, the principal method of malaria vector control in Sri Lanka. Sri Lanka has undertaken different insecticide regimes at different times over the last six decades for malaria

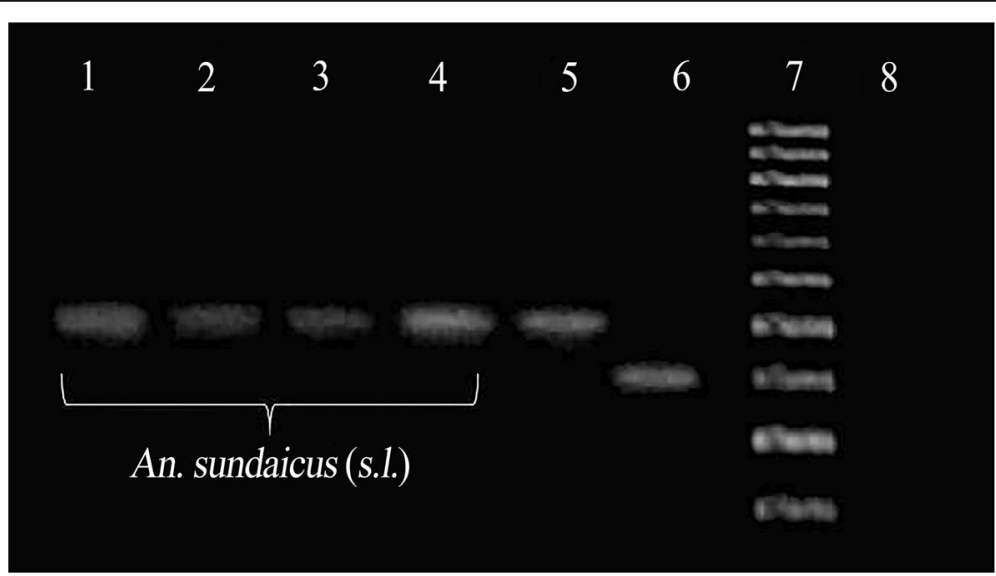

Fig. 2 Agarose gel image of species-specific PCR assay to identify An. sundaicus complex from An. subpictus complex. The diagnostic size of the PCR product is 400 bp for An. sundaicus complex. Lanes 1-4: An. sundaicus (s.l.) samples; Lane 5: An. sundaicus (s.l.) positive control from a previous study [10]; Lane 6: An. subpictus species A control from previous study [10]; Lane 7: 100 bp DNA ladder as size marker; Lane 8: negative PCR control without added DNA 
control [18, 23]. DDT introduced at the end of World War 2 for IRS was highly effective in controlling malaria until resistance developed in the 1960s and 1970s, causing it to be replaced by the organophosphate malathion in 1977. Pyrethroids have been used for IRS since 1994 on the whole island except for the Northern Province due to the development of resistance to malathion [1]. However, IRS has been scaled down or has ceased since 2013 in the island and is now only performed in the vicinity of the residences of persons identified to have contracted malaria abroad.

In northern Sri Lanka, malaria control activities were curtailed in the Jaffna and Kilinochchi districts during the civil war as the regional AMC faced logistical problems and a shortage of resources. Vector control activities in the Jaffna and Kilinochchi districts in the Northern Province were mainly restricted to IRS with malathion until 2002 when it was replaced by the pyrethroid deltamethrin [15].

High susceptibility to common insecticides shown by An. sundaicus (s.l.) populations from other parts of the country was attributed to its exophagic and exophilic nature [18]. However, collection of An. sundaicus (s.l.) in IC and $\mathrm{CBH}$ techniques during the present and an earlier study [15], along with high sporozoite rates [17], indicates some endophagic and endophilic behavior in northern Sri Lanka, for which IRS and insecticidetreated bed nets can be effective. Our previous study on the resistance and resistance mechanisms in Eastern and North Western provinces in coastal areas of mainland Sri Lanka (Fig. 1) suggested that An. sundaicus (s.l.) populations were resistant to DDT but relatively susceptible to malathion and pyrethroids [18], compatible with the present observations in Northern Province. Cessation of malathion use for IRS since 1994 on the whole island and in Northern Province in 2002, along with the careful use of pyrethroids for IRS and its cessation in 2006, may contribute to the continued relative susceptibility to the two insecticides. Development of resistance is associated with a fitness cost and mosquito populations can in time lose resistance in the absence of insecticide selection pressure [28, 29]. It is pertinent, however, that organophosphate and pyrethroid insecticides continue to be used for agricultural purposes and personal protection, respectively, in Sri Lanka [30], and this might eventually contribute to the development of resistance to the two classes of insecticides.

\section{Conclusions}

The results suggest that malathion and deltamethrin may still be effectively used to control Anopheles sundaicus (s.l.) in the Jaffna and Kilinochchi districts but indicate the need for continued monitoring of insecticide resistance in the two districts and elsewhere in the country.

\section{Abbreviations}

AChE: Acetylcholinesterase; AMC: Anti-Malaria Campaign;

DDT: Dichlorodiphenyltrichloroethane; EST: Esterase; GST: Glutathione Stransferase; IRS: Indoor residual spraying; MO: Monooxygenase;

PCR: Polymerase chain reaction

\section{Acknowledgments}

Members of the Entomology Team of the Regional Malaria Office of the districts of Kilinochchi and Jaffna are acknowledged for their field assistance.

\section{Funding}

The study received financial assistance from National Science Foundation of Sri Lanka (NSF/BT/2011/04).

Availability of data and materials

All data generated during this study are included in this published article.

\section{Authors' contributions}

SNS conceptualized and designed the project. KS and AT performed mosquito collections. KS performed identification, molecular analysis and bioassays. KS and TW performed biochemical assays. SNS, KS, SHPPK and RR analyzed data and wrote the manuscript. All authors read and approved the final manuscript.

\section{Ethics approval and consent to participate}

No specific permits or approval were required for collection of mosquitoes. The study did not involve endangered or protected species. Mosquitoes were collected and reared in the insectary as per the approved (AERC/2014/02) protocol of the Institutional Animal Ethics Committee of the University of Jaffna. Verbal informed consent was obtained from householders to set up traps in their premises.

\section{Consent for publication}

Not applicable.

\section{Competing interests}

The authors declare that they have no competing interests.

\section{Publisher's Note}

Springer Nature remains neutral with regard to jurisdictional claims in published maps and institutional affiliations.

\section{Author details}

${ }^{1}$ Department of Zoology, Faculty of Science, University of Jaffna, Jaffna, Sri Lanka. ${ }^{2}$ Department of Zoology, Faculty of Science, University of Peradeniya, Peradeniya, Sri Lanka. ${ }^{3}$ Office of the Provincial Director of Health Services, Jaffna, Sri Lanka.

${ }^{4}$ ID-FISH Technology Inc., Palo Alto, California, USA.

Received: 30 May 2018 Accepted: 4 December 2018

Published online: 07 January 2019

\section{References}

1. Wijesundere DA, Ramasamy R. Analysis of historical trends and recent elimination of malaria from Sri Lanka and its applicability for malaria control in other countries. Front Public Health. 2017:5:212.

2. Dharmasiri AGG, Perera AY, Harishchandra J, Herath H, Aravindan K, Jayasooriya HRT, et al. First record of Anopheles stephensi in Sri Lanka: a potential challenge for prevention of malaria reintroduction. Malar J. 2017; 16:326.

3. Surendran SN, Sivabalakrihsnan K, Gajapathy K, Arthiyan S, Jayadas TTP, Karvannan K, et al. Genotype and biotype of invasive Anopheles stephensi in Mannar Island of Sri Lanka. Parasit Vectors. 2018;11:3.

4. Amerasinghe PH, Amerasinghe FP, Wirtz RA, Indrajith NG, Somapala W, Pereira LR, et al. Malaria transmission by Anopheles subpictus Grassi in a new irrigation project in Sri Lanka. J Med Entomol. 1992;29:577-81.

5. Amerasinghe PH, Amerasinghe FP, Kondradsen F, Fonseka KT, Wirtz RA. Malaria vectors in a traditional dry zone village in Sri Lanka. Am J Trop Med Hyg. 1999;60:421-9.

6. Ramasamy R, De Alwis R, Wijesundera A, Ramasamy MS. Malaria transmission in a new irrigation scheme in Sri Lanka: the emergence of Anopheles annularis as a major vector. Am J Trop Med Hyg. 1992;47:547-53. 
7. Ramasamy R, Ramasamy MS, Wijesundera DA, Dewit I, Wijesundera AP Pathirana $S$, et al. High seasonal malaria transmission rates in the intermediate rainfall zone of Sri Lanka. Ann Trop Med Parasitol. 1992;86: 591-600.

8. Surendran SN, Ramasamy MS, de Silva BGDNK, Ramasamy R. Anopheles culicifacies sibling species B and E in Sri Lanka differ in longevity and in their susceptibility to malaria parasite infection and common insecticide. Med Vet Entomol. 2006;20:153-6.

9. Surendran SN, Jude PJ, Singh OP, Ramasamy R. Genetic evidence for the presence of malaria vectors of Anopheles sundaicus complex in Sri Lanka with morphological characteristics attributed to Anopheles subpictus species B. Malar J. 2010;9:343.

10. Surendran SN, Sarma DK, Jude PJ, Kemppainen P, Kanthakumaran N, Gajapathy K, et al. Molecular characterization and identification of members of the Anopheles subpictus complex in Sri Lanka. Malar J. 2013;12:304.

11. Surendran SN, Ramasamy R. The Anopheles culicifacies and An. subpictus complexes in Sri Lanka and their implications for malaria control in the country. Trop Med Health. 2010;38:1-11.

12. Jude PJ, Ramasamy R, Surendran SN. Bionomic aspects of the Anopheles subpictus species complex in Sri Lanka. J Insect Sci. 2014;14:97.

13. Sinka ME, Bangs MJ, Manguin S, Chareonviriyaphap T, Patil AP, Temperley $\mathrm{WH}$, et al. The dominant Anopheles vectors of human malaria in the AsiaPacific region: occurrence data, distribution maps and bionomic précis. Parasit Vectors. 2011:4:89.

14. Ramasamy R, Surendran SN. Global climate change and its potential impact on disease transmission by salinity-tolerant mosquito vectors in coastal zones. Front Physiol. 2012;3:198.

15. Kannathasan S, Antonyrajan A, Srikrishnaraj KA, Karunaratne SHPP, Karunaweera ND, Surendran SN. Studies on prevalence of anopheline species and community perception of malaria in Jaffna District, Sri Lanka. J Vector Borne Dis. 2008;45:231-9.

16. Thevarasa C, Rajendram GF. A survey of anopheline mosquitoes in Jaffna Peninsula in Sri Lanka. Proc Jaffna Sci Assoc. 1995;4:5.

17. Thevarasa C, Rajendram GF. Malaria transmission by Anopheles species in Jaffna Peninsula. Proc Jaffna Sci Assoc. 1995;4:20.

18. Surendran SN, Jude PJ, Weerarathne TC, Karunaratne SHPP, Ramasamy R. Variations in susceptibility to common insecticides and resistance mechanisms among morphologically identified sibling species of the malaria vector Anopheles subpictus in Sri Lanka. Parasit Vectors. 2012;5:34

19. Amerasinghe FP. A guide to the identification of the anopheline mosquitoes (Diptera: Culicidae) of Sri Lanka. I. Adult females. Cey J Sci (Biol Sci). 1990:21:116

20. Surendran SN, Ramasamy MS, de Silva BGDNK, Ramasamy R. Anopheles culicifacies sibling species B and E in Sri Lanka differ in longevity and in their susceptibility to malaria parasite infection and common insecticides. Med Vet Entomol. 2006;20:153-6.

21. WHO. Criteria and meaning of tests for determining susceptibility or resistance of insects to insecticides. WHO Technical report series. Geneva: World Health Organization; 1963. p. 135-8.

22. WHO. Test procedures for insecticide resistance monitoring in malaria vector mosquitoes. Geneva: World Health Organization; 2016.

23. Perera MDB, Hemingway J, Karunaratne SHPP. Multiple insecticide resistance mechanisms involving metabolic changes and insensitive target sites selected in anopheline vectors of malaria in Sri Lanka. Malar J. 2008;7:168.

24. WHO. Techniques to detect insecticide resistance mechanisms (field and laboratory manual). Geneva: World Health Organization; 1998.

25. Konradsen F, Amerasinghe FP, Hoek Van der W, Amerasinghe PH. Malaria in Sri Lanka; current knowledge on transmission and control. Colombo, Sri Lanka: International Water management Institute; 2000.

26. Hemingway J, Miyamoto J, Herath PRJ. A possible novel link between organophosphorus and DDT insecticide resistance gene in Anopheles supporting evidence from fenitrothion metabolism studies. Pest Biochem Physiol. 1991;39:49-56.

27. Herath PRJ, Jayawardena KGJ. DDT resistance in Anopheles culicifacies Giles and A. subpictus Grassi (Diptera: Culicidae) from Sri Lanka: a field study on the mechanisms and changes in gene frequency after on the mechanisms and changes in gene frequency after cessation of DDT spraying. Bull Entomol Res. 1988;78:717-23.

28. Tabbabi A, Daaboub J. Fitness cost in field Anopheles labranchiae populations associated with resistance to the insecticide deltamethrin. Med Vet Entomol. 2018;62:107-11.
29. Platt N, Kwiatkowska RM, Irving H, Diabate A, Dabire R, Wondji CS. Targetsite resistance mutations ( $k d r$ and $R D L$ ), but not metabolic resistance, negatively impact male mating competiveness in the malaria vector Anopheles gambiae. Heredity. 2015;115:243-52

30. Ramasamy R, Jude PJ, Veluppillai T, Eswaramohan T, Surendran SN. Biological differences between brackish and fresh water-derived Aedes aegypti from two locations in the Jaffna Peninsula of Sri Lanka and the implications for arboviral disease transmission. PLoS One. 2014;8:e104977.
Ready to submit your research? Choose BMC and benefit from:

- fast, convenient online submission

- thorough peer review by experienced researchers in your field

- rapid publication on acceptance

- support for research data, including large and complex data types

- gold Open Access which fosters wider collaboration and increased citations

- maximum visibility for your research: over $100 \mathrm{M}$ website views per year

At BMC, research is always in progress.

Learn more biomedcentral.com/submissions 